\title{
10. GEOCHEMISTRY AND CARBONATE PETROLOGY OF SELECTED SEDIMENT SAMPLES FROM DEEP SEA DRILLING PROJECT LEG 54, EASTERN PACIFIC
}

\author{
Ed L. Schrader, ${ }^{1}$ Department of Geology, Duke University, Durham, North Carolina \\ W. J. Furbish, Department of Geology, Duke University, Durham, North Carolina \\ David Mattey, Department of Geology, Bedford College, London, England \\ and \\ J. A. May, Department of Geology, Rice University, Houston, Texas
}

\begin{abstract}
Thirty selected samples of pelagic and hydrothermal sediments retrieved on DSDP Leg 54 were chemically analyzed for major and minor oxide concentrations. Additionally, 11 samples of lithified carbonate sediments were petrologically studied.

The pelagic sediments, which are described as foraminiferal biomicrite, were found to be generally higher in $\mathrm{Fe}$ and $\mathrm{Zn}$, similar in $\mathrm{Co}$ content, and lower in $\mathrm{Cu}$ content, than the average Pacific pelagic sediments. Mineralogically, these samples are composed principally of calcite with minor amounts of quartz and clays.

Hydrothermal sediments from Site 424 are divisible into three classes: (1) silica-rich, iron-poor smectites; (2) silica-poor, iron-rich mixtures of smectites and oxides; and (3) silica-poor, iron-rich materials, comprising mainly amorphous manganese oxides. Thus, two chemically distinct hydrothermal phases are recognizable: Class 1, iron-rich smectites, and Class 3, Mn-rich oxides and oxyhydroxides.

Dolomite and pyrite were identified in X-ray diffraction studies of samples from Site 427.
\end{abstract}

\section{INTRODUCTION}

During Leg 54, the D/V Glomar Challenger recovered sediments from three discrete geologic environments (Figure 1): (1) from the flanks of the active, rapidly spreading East Pacific Rise (EPR) crest (Sites 419, $420,421,422,423,428$, and 429); (2) from an area of known high heat flow and probable hydrothermal affinity near the Galapagos Spreading Center (Site 424); and (3) from the topographic low created by the active Siqueiros transform fault (Site 427). An additional site, Site 425 , was placed on the northern flank of the Galapagos Rift.

The general geochemistry of sediments along the EPR has been previously discussed by Cronan and Garret (1973), Cronan (1976), Boström et al. (1976), Boström et al. (1973), and many others. The present study was undertaken: (1) to determine if similarities exist between hydrothermal deposits near the Galapagos Rift and other sediments previously described as hydrothermal (Hoffert et al., 1978); (2) to establish quantitative relationships among trace metals without recalculating them to a theoretical "carbonate free" value: (3) to provide a general description of sediment adjacent to spreading centers and transform faults of the Central East Pacific; and (4) to describe the petrology of lithified portions of the carbonate sediments which occur as lumps or nodules in the cores obtained on Leg 54 .

\footnotetext{
${ }^{1}$ Present address: Department of Geology/Geography, The University of Alabama, University, Alabama.
}

\section{CHEMICAL RESULTS AND DISCUSSIONS}

\section{Analytical Procedure}

Between one and nine representative samples were selected per site for chemical studies, but several of the sites include more than one hole (Table $1 \mathrm{a}$ and $\mathrm{b}$ ). In addition, 11 lithified samples were taken for petrographic studies (Table 2). Additional lithologic descriptions of the sediments are given in the appropriate Site Reports of this volume. Conventional atomic absorption analysis techniques were used to determine $\mathrm{Fe}, \mathrm{Mn}, \mathrm{Au}, \mathrm{Co}$, $\mathrm{Zn}$, and $\mathrm{Mo}$. $\mathrm{Ca}, \mathrm{K}, \mathrm{P}, \mathrm{Ti}, \mathrm{Zn}, \mathrm{Y}, \mathrm{Rb}, \mathrm{Nb}$, and $\mathrm{Sr}$ were determined by X-ray fluorescence spectroscopy, using compressed powder pellets. USGS and other international standards were used to calibrate both methods, and the overall precisions are estimated as better than \pm 5 per cent. Detection limits for $\mathrm{Zr}, \mathrm{Y}, \mathrm{Rb}$, and $\mathrm{Nb}$ are $10 \mathrm{ppm}, 5 \mathrm{ppm}, 1 \mathrm{ppm}$, and $1 \mathrm{ppm}$, respectively.

The large errors possible when calculating "carbonate free" values and other compensatory techniques (such as norm calculations) which are not yet proven reliable, led the authors to choose representation of all chemical data in its original, bulk sample form. No recalculations or other data manipulations have been performed. Chemical data for 30 sediment samples are presented in Table 1.

\section{Fe and Mn Relationships}

Fe concentrations range between 2 per cent and 26 per cent throughout the sample group. Most values fall between 5 per cent and 10 per cent $\mathrm{Fe}$. Mn values are 


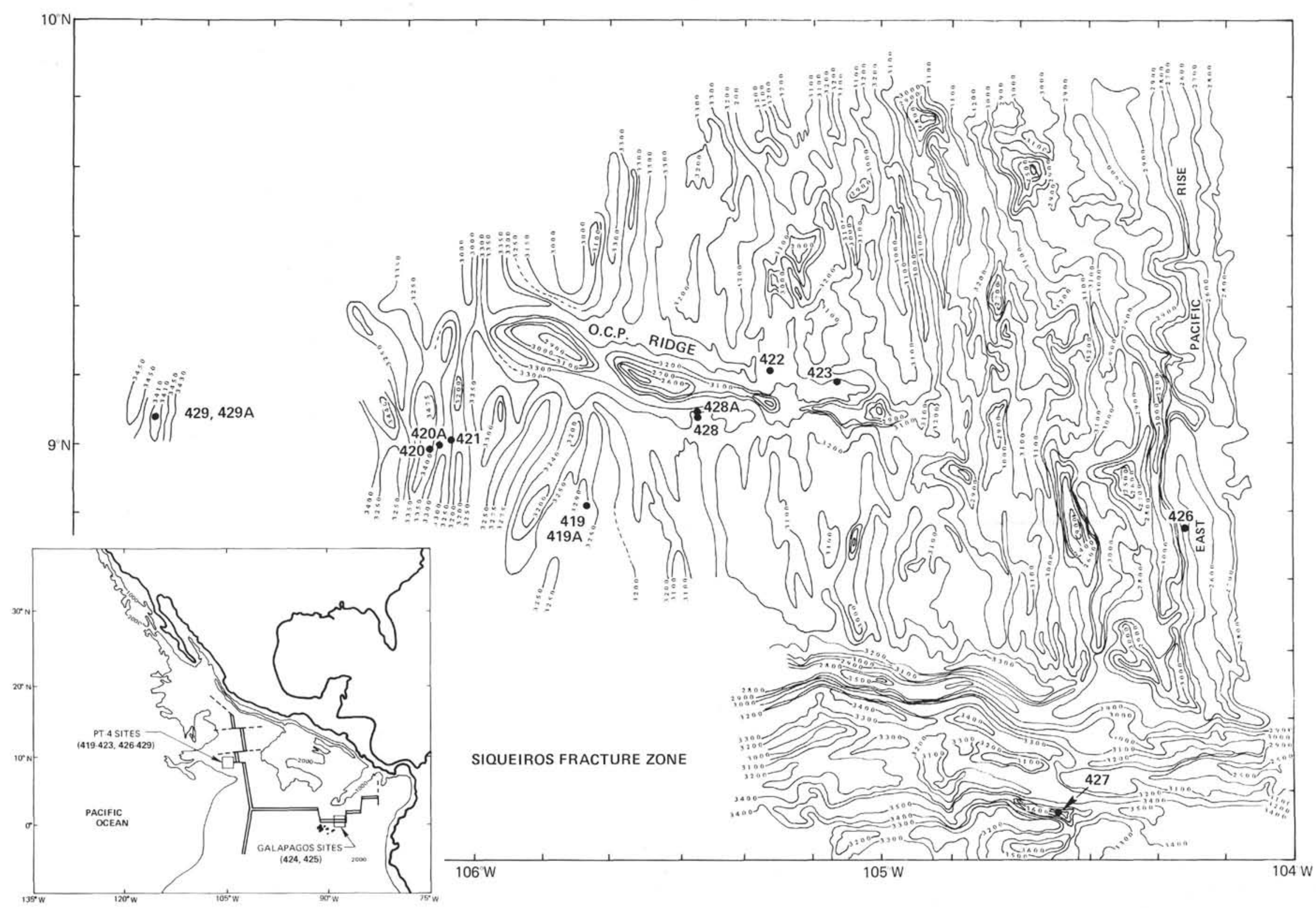

Figure 1. Location of Deep Sea Drilling Project sites for Leg 54. 
GEOCHEMISTRY AND CARBONATE PETROLOGY

TABLE 1a

Concentration of Trace Metals (ppm) in Sediments by Atomic Absorption Analyses ${ }^{a}$

\begin{tabular}{|c|c|c|c|c|c|c|}
\hline $\begin{array}{c}\text { Sample } \\
\text { (Interval in cm) }\end{array}$ & $\mathrm{Fe}$ & $\mathrm{Mn}$ & $\mathrm{Cu}$ & Co & $\mathrm{Zn}$ & Mo \\
\hline \multicolumn{7}{|l|}{ Hole 419} \\
\hline $\begin{array}{l}1, C C, 2-4 a \\
2-3,53-55 a \\
3-1,91-93 a \\
4-2,92-94 b \\
4-5,13-15 b \\
5, C C, 1-2 a\end{array}$ & $\begin{array}{l}76,786 \\
74,306 \\
85,728 \\
93,006 \\
99,777 \\
69,115\end{array}$ & $\begin{array}{r}3,233 \\
2,890 \\
4,082 \\
2,232 \\
97,781 \\
1,580\end{array}$ & $\begin{array}{r}177.8 \\
156.4 \\
187.8 \\
177.8 \\
123.7 \\
79.0\end{array}$ & \begin{tabular}{r|}
48.5 \\
90.8 \\
102.6 \\
339.0 \\
43.9 \\
67.1
\end{tabular} & $\begin{array}{l}327.4 \\
214.7 \\
240.9 \\
421.6 \\
355.2 \\
177.8\end{array}$ & $\begin{array}{l}56.6 \\
- \\
- \\
55.9 \\
-\end{array}$ \\
\hline \multicolumn{7}{|l|}{ Hole 419A } \\
\hline $1-3,132-34 a$ & 50,615 & 1,539 & 178.2 & 145.8 & 465.7 & 76.9 \\
\hline \multicolumn{7}{|l|}{ Hole 420} \\
\hline $\begin{array}{l}1-1,10-12 \mathrm{c} \\
1-1,129-31 \mathrm{a} \\
2-3,70-72 \mathrm{a} \\
9-1,10-12 \mathrm{~d} \\
10-2,41-43 \mathrm{e} \\
11-2,15-17 \mathrm{e} \\
12-2,50-52 \mathrm{f} \\
13-4,130-32 \mathrm{f}\end{array}$ & $\begin{array}{r}71,557 \\
66,203 \\
105,460 \\
36,012 \\
80,749 \\
47,985 \\
50,225 \\
60,562\end{array}$ & $\begin{array}{r}20,445 \\
6,041 \\
29,449 \\
136,044 \\
8,882 \\
2,319 \\
2,652 \\
2,423\end{array}$ & $\begin{array}{r}188.1 \\
132.4 \\
254.7 \\
172.1 \\
205.9 \\
96.0 \\
64.3 \\
310.9\end{array}$ & $\begin{array}{r}163.6 \\
74.5 \\
127.4 \\
96.0 \\
64.6 \\
96.0 \\
92.4 \\
56.5\end{array}$ & $\begin{array}{l}462.1 \\
211.0 \\
350.2 \\
208.1 \\
298.8 \\
104.0 \\
136.6 \\
165.5\end{array}$ & $\begin{array}{l}57.3 \\
57.9 \\
59.7 \\
48.0 \\
72.7 \\
44.0 \\
\overline{72.7}\end{array}$ \\
\hline \multicolumn{7}{|l|}{ Hole $420 \mathrm{~A}$} \\
\hline $1-1,24-26 \mathrm{c}$ & 92,638 & 14,822 & 263.5 & 74.1 & 275.9 & 49.4 \\
\hline \multicolumn{7}{|l|}{ Hole 424} \\
\hline $\begin{array}{l}1-1,2-4 \mathrm{~g}^{*} \\
1-1,97-99 \mathrm{~g}, \mathrm{a} \\
2-1,50-52 \mathrm{~g} \\
2-4,29-31 \mathrm{~g}, \mathrm{a} \\
2-4,130-32 \mathrm{a} \\
3-1,27-29 \mathrm{~g} \\
4-6,83-85 \mathrm{a}, \mathrm{g}\end{array}$ & $\begin{array}{r}99,396 \\
165,235 \\
240,077 \\
259,465 \\
134,922 \\
211,081 \\
21,495\end{array}$ & $\begin{array}{r}286,260 \\
40,069 \\
1,601 \\
4,982 \\
1,827 \\
38,598 \\
4,547\end{array}$ & $\begin{array}{r}151.1 \\
190.0 \\
112.1 \\
99.6 \\
116.2 \\
172.9 \\
190.2\end{array}$ & $\begin{array}{l}31.8 \\
28.9 \\
16.0 \\
37.4 \\
58.1 \\
40.2 \\
53.7\end{array}$ & $\begin{array}{r}83.5 \\
400.7 \\
36.0 \\
49.8 \\
78.9 \\
80.4 \\
86.9\end{array}$ & $\begin{array}{r}373.7 \\
90.9 \\
64.0 \\
62.3 \\
49.8 \\
120.6 \\
41.3\end{array}$ \\
\hline \multicolumn{7}{|l|}{ Hole 424A } \\
\hline $1-1,77-79 g^{*}$ & 115,435 & 71,735 & 119.6 & 28.9 & 630.8 & 239.1 \\
\hline \multicolumn{7}{|l|}{ Hole 424B } \\
\hline $1-2,67-69 \mathrm{~g}, \mathrm{a}^{*}$ & 49,968 & 1,839 & 123.9 & 28.0 & 103.9 & 60.0 \\
\hline \multicolumn{7}{|l|}{ Hole 425} \\
\hline $1-1,13-15 a$ & 34.430 & 2.187 & 206.6 & 36.5 & 243.0 & 44.6 \\
\hline \multicolumn{7}{|l|}{ Hole 427} \\
\hline $\begin{array}{l}2-1,30-32 \mathrm{a} \\
3-3,81-83 \mathrm{~h} \\
8-1,18-20 \mathrm{a}\end{array}$ & $\begin{array}{r}49,793 \\
175,139 \\
51,415\end{array}$ & $\begin{array}{r}258,923 \\
21,994 \\
11,928\end{array}$ & $\begin{array}{l}175.2 \\
228.1 \\
205.7\end{array}$ & $\begin{array}{l}191.2 \\
350.4 \\
172.8\end{array}$ & $\begin{array}{l}235.0 \\
297.3 \\
246.8\end{array}$ & $\begin{array}{r}39.8 \\
154.8 \\
49.4\end{array}$ \\
\hline \multicolumn{7}{|l|}{ Hole 429} \\
\hline $1-1.90-92 \mathrm{a}$ & 57,283 & 6,547 & 188.2 & 57.3 & 155.5 & 57.3 \\
\hline
\end{tabular}

*Tabulated values of sediment from the Mounds Hydrothermal Field are derived from bulk samples and may represent mixtures of carbonate ooze, silica-poor and silica-rich hydrothermal deposits as defined in this paper. Samples analyzed for this Initial Reports volume maintain the integrity of shipboard sampling. Analyses of hand-separated, carbonate-free portions of the sediment are reported in the Site 424 Report.

\footnotetext{
Note: $\mathrm{a}=$ Foraminifer-nannofossil ooze. $\mathrm{b}=$ Radiolarian-nannofossil ooze.

$\mathrm{c}=$ Brown calcareous clay.

$d=$ Lithified siliceous nannofossil ooze

$\mathrm{e}=$ Siliceous nannofossil ooze.

$$
\begin{aligned}
\mathrm{f}= & \text { Nannofossil ooze. } \\
\mathrm{g}= & \text { Mixture of Mn oxide frag- } \\
& \text { ments and green clay. }
\end{aligned}
$$$$
\mathrm{h}=\text { Calcareous siliceous ooze. }
$$

generally lower, with the major portion of samples having values between 1 per cent and 7 per cent. The spectrum of Mn concentrations runs from 1.5 per cent to 29 per cent. Fe generally correlates positively with $\mathrm{Mn}$. In only three specimens does $\mathrm{Mn}$ become more concentrated than Fe (Samples 420-9-1, 10-12 cm; 424-1-1, 2-4 $\mathrm{cm}$; and 427-2-1, 30-32 cm).
TABLE 1b

\begin{tabular}{|c|c|c|c|c|c|c|c|c|c|}
\hline $\begin{array}{c}\text { Sample } \\
\text { (Interval in cm) }\end{array}$ & $\mathrm{CaO}$ & $\mathrm{K}_{2} \mathrm{O}$ & $\mathrm{P}_{2} \mathrm{O}_{5}$ & $\mathrm{TiO}_{2}$ & $\mathrm{Zr}$ & $\mathrm{Y}$ & $\mathrm{Rb}$ & $\mathrm{Nb}$ & Sr \\
\hline \multicolumn{10}{|l|}{ Hole 419} \\
\hline $\begin{array}{l}1, \mathrm{CC}, 2-4 \\
2-3,53-55 \\
3-1,91-93 \\
4-2,92-94 \\
4-5,13-15 \\
5, \mathrm{CC}, 1-2\end{array}$ & $\begin{array}{l}28.73 \\
36.00 \\
31.64 \\
10.03 \\
20.16 \\
37.30\end{array}$ & $\begin{array}{l}1.31 \\
1.23 \\
1.16 \\
1.50 \\
1.55 \\
1.35\end{array}$ & $\begin{array}{l}0.40 \\
0.43 \\
0.50 \\
0.22 \\
0.23 \\
0.31\end{array}$ & $\begin{array}{l}0.23 \\
0.22 \\
0.28 \\
0.27 \\
0.19 \\
0.14\end{array}$ & $\begin{array}{l}64 \\
50 \\
68 \\
41 \\
63 \\
47\end{array}$ & $\begin{array}{l}53 \\
45 \\
49 \\
37 \\
41 \\
37\end{array}$ & $\begin{array}{l}16 \\
21 \\
23 \\
20 \\
28 \\
22\end{array}$ & $\begin{array}{l}4 \\
3 \\
3 \\
0 \\
3 \\
1\end{array}$ & $\begin{array}{l}708 \\
817 \\
728 \\
305 \\
510 \\
761\end{array}$ \\
\hline \multicolumn{10}{|l|}{ Hole 419A } \\
\hline $1-3,132-134$ & 27.37 & 1.53 & 0.42 & 0.25 & 70 & 68 & 26 & 3 & 690 \\
\hline \multicolumn{10}{|l|}{ Hole 420} \\
\hline $\begin{array}{l}1-1,10-2 \\
1-1,129-131 \\
2-3,70-72 \\
9-1,10-12 \\
10-2,41-43 \\
11-2,15-17 \\
12-2,50-52 \\
13-4,130-132\end{array}$ & $\begin{array}{l}28.84 \\
32.06 \\
12.16 \\
19.69 \\
11.50 \\
26.05 \\
43.46 \\
41.80\end{array}$ & $\begin{array}{l}1.03 \\
1.20 \\
1.49 \\
0.83 \\
1.53 \\
2.98 \\
1.07 \\
1.35\end{array}$ & $\begin{array}{l}0.55 \\
0.40 \\
0.56 \\
0.33 \\
0.27 \\
0.25 \\
0.40 \\
0.40\end{array}$ & $\begin{array}{l}0.27 \\
0.21 \\
0.45 \\
0.16 \\
0.30 \\
0.17 \\
0.12 \\
0.14 \\
\end{array}$ & $\begin{array}{r}72 \\
57 \\
100 \\
32 \\
88 \\
75 \\
35 \\
43\end{array}$ & $\begin{array}{l}50 \\
47 \\
74 \\
33 \\
69 \\
25 \\
41 \\
45\end{array}$ & $\begin{array}{l}18 \\
23 \\
34 \\
14 \\
34 \\
64 \\
17 \\
22\end{array}$ & $\begin{array}{l}4 \\
2 \\
4 \\
1 \\
4 \\
2 \\
2 \\
1\end{array}$ & $\begin{array}{r}873 \\
712 \\
664 \\
474 \\
509 \\
773 \\
982 \\
1050\end{array}$ \\
\hline \multicolumn{10}{|l|}{ Hole 420A } \\
\hline $1-1,24-26$ & 27.52 & 1.17 & 0.53 & 0.29 & 68 & 50 & 22 & 1 & 801 \\
\hline \multicolumn{10}{|l|}{ Hoie 424} \\
\hline $\begin{array}{l}1-1,2-4 \\
1-1,97-99 \\
2-1,50-52 \\
2-4,29-31 \\
2-4,130-132 \\
3-1,20-29 \\
4-6,83-85\end{array}$ & $\begin{array}{r}2.19 \\
0.74 \\
0.34 \\
1.29 \\
14.62 \\
0.73 \\
1.01\end{array}$ & $\begin{array}{l}1.27 \\
2.39 \\
3.46 \\
3.58 \\
2.06 \\
3.20 \\
0.61\end{array}$ & $\begin{array}{l}0.22 \\
0.13 \\
0.07 \\
0.10 \\
0.13 \\
0.10 \\
0.52\end{array}$ & $\begin{array}{l}0.07 \\
0.04 \\
0.04 \\
0.05 \\
0.13 \\
0.04 \\
0.09\end{array}$ & $\begin{array}{r}2 \\
1 \\
1 \\
2 \\
18 \\
2 \\
14\end{array}$ & $\begin{array}{r}6 \\
1 \\
0 \\
3 \\
15 \\
2 \\
11\end{array}$ & $\begin{array}{r}12 \\
51 \\
70 \\
65 \\
37 \\
57 \\
8\end{array}$ & $\begin{array}{l}0 \\
0 \\
2 \\
0 \\
1 \\
0 \\
0\end{array}$ & $\begin{array}{r}259 \\
75 \\
27 \\
52 \\
366 \\
61 \\
975\end{array}$ \\
\hline \multicolumn{10}{|l|}{ Hole 424A } \\
\hline $\begin{array}{l}1-1,77-79 \\
\text { (duplicate) }\end{array}$ & $\begin{array}{l}7.53 \\
7.47\end{array}$ & $\begin{array}{l}1.59 \\
1.45\end{array}$ & $\begin{array}{l}0.17 \\
0.17\end{array}$ & $\begin{array}{l}0.17 \\
0.16\end{array}$ & $\begin{array}{l}15 \\
17\end{array}$ & $\begin{array}{l}9 \\
9\end{array}$ & $\begin{array}{l}31 \\
33\end{array}$ & $\begin{array}{l}0 \\
0\end{array}$ & $\begin{array}{l}270 \\
276\end{array}$ \\
\hline \multicolumn{10}{|l|}{ Hole 424B } \\
\hline \multicolumn{10}{|l|}{ Hole 425} \\
\hline $1-1,13-15$ & 37.37 & 0.77 & 0.29 & 0.14 & 28 & 20 & 9 & 1 & 856 \\
\hline \multicolumn{10}{|l|}{ Hole 427} \\
\hline $\begin{array}{l}2-1,30-32 \\
3-3,81-83 \\
8-1,18-20\end{array}$ & $\begin{array}{r}20.02 \\
4.20 \\
13.04\end{array}$ & $\begin{array}{l}0.18 \\
0.89 \\
0.79\end{array}$ & $\begin{array}{l}0.99 \\
0.26 \\
0.21\end{array}$ & $\begin{array}{l}0.10 \\
0.23 \\
0.18\end{array}$ & $\begin{array}{l}10 \\
57 \\
50\end{array}$ & $\begin{array}{l}11 \\
43 \\
36\end{array}$ & $\begin{array}{r}1 \\
17 \\
14\end{array}$ & $\begin{array}{l}1 \\
0 \\
2\end{array}$ & $\begin{array}{l}198 \\
258 \\
462\end{array}$ \\
\hline
\end{tabular}

Concentration (ppm) of Selected Elements in Sediments by XRF Analyses

Hole 429

\begin{tabular}{llllllllll}
$1-1,90-29$ & 43.10 & 0.82 & 0.47 & 0.12 & 36 & 41 & 10 & 1 & 1058 \\
\hline
\end{tabular}

Reversals of $\mathrm{Fe} / \mathrm{Mn}$ ratios (i.e., when $\mathrm{Mn} \%>\mathrm{Fe} \%$ ) relate an atypical segregation of these cations in the geochemical cycle. Such concentration of Mn may lead to deposition of Mn oxide ore deposits. It has been explained in the past (Natland, 1973; Dymond et al., 1976) that abnormally high concentrations of $\mathrm{Fe}$ and $\mathrm{Mn}$ oxides in sediments other than $\mathrm{Fe} / \mathrm{Mn}$ nodules may indicate hydrothermal deposition. The extreme concentration of $\mathrm{Mn}$ to the exclusion of $\mathrm{Fe}$ in diagenetic fluids or connate brines is inherenetly difficult, since the two elements so closely follow one another in sedimentary geochemical cycles (Stanton, 1972; Krauskopf, 1967). With this factor in mind, we see such $\mathrm{Fe} / \mathrm{Mn}$ ratio reversals as at least suggesting the effects of previously heated, circulating fluids on the sediments. Such fluids may have a geochemical buffer or magmatic component favoring 
TABLE 2

Lithified Sediment

Specimens Used in

Carbonate Petro-

logic Study

Sample

(Interval in $\mathrm{cm}$ )

420-9-1, 10-12

$420-10-3,78-80$

$420-11-1,10-12$

424-3-2, 3-5

$424-3-3,77-79$

423-4-2, 51-53

$423-3-4,130-132$

$424 \mathrm{~A}-2-1,78-80$

424A-4-1, 35-37

$427-2-1,30-32$

$427-2-6,74-76$

the precipitation of $\mathrm{Fe}$ at depth and the continued migration of Mn to be deposited at the surface (Krauskopf, 1957).

\section{$\mathrm{Zr}$ and $\mathrm{Y}$ Relationships}

The high concentrations of $\mathrm{Zr}$ and $\mathrm{Y}$ correlate positively with the content of volcanic glass in the sediments. Since no detrital minerals containing $\mathrm{Zz}$ and $\mathrm{Y}$ were observed in polished thin section or X-ray diffraction studies, we infer that these pneumatophyle cations are trapped in the silicate glass. Upon hydration of the glass, leaching of trapped constituents is possible. In such cases the Fe-Mn oxides coating sediment grains may adsorb these positively charged particles.

In sediment from Site $420, \mathrm{Zr}$ exhibits concentrations of $72,100,88$, and $75 \mathrm{ppm}$, while $\mathrm{Y}$ values of 50,60 , and $74 \mathrm{ppm}$ are recorded. At other sites the highest $\mathrm{Zr}$ values never exceed $65 \mathrm{ppm}$ and $\mathrm{Y}$ does not exceed 55 ppm. Hydrated volcanic glass comprises about 50 per cent of the pyroclastic component in the Site 420 sediments. Fe coatings on many carbonate grains, as well as Fe-Mn oxide masses, are common throughout Site 420. The $\mathrm{Zr}$ and $\mathrm{Y}$ are believed to be associated with these oxides, probably as adsorbed ions or interstitialy trapped constituents.

\section{ELEMENTAL VARIATIONS AND DESCRIPTIVE GEOCHEMISTRY OF SITE 424}

The anomalous distribution of cations and oxides in Site 424 is indicative of a nonsedimentary origin. A variety of contributing factors suggest a hydrothermal origin. The $\mathrm{Zr}, \mathrm{Y}, \mathrm{Nb}, \mathrm{Co}$, and $\mathrm{TiO}_{2}$ contents of the Hole 424 sediments are generally much lower than those of the other sample sites. Sr, Mo, and $\mathrm{Zn}$ concentrations fluctuate strongly, perhaps as a response to pulses of hydrothermal activity, some of which were richer in Mo and/or $\mathrm{Zn}$ than in $\mathrm{Sr}$. The similar ionic radius and charge of $\mathrm{Sr}$ and $\mathrm{Ca}$ allow diadochy between these cations. Sr correlates with $\mathrm{CaO}$, whose concentration is directly related to the total calcite content. Thus, the greater volumes of hydrothermal silicates and oxides may dilute the normal calcite bearing sediments, and the $\mathrm{Sr}$ becomes concomitantly lower. In Hole 424, $\mathrm{Sr}$ deviates strongly from $\mathrm{Ca}$ in the stratigraphically lowest sample from the core, implying a nonsedimentary affiliation of the enriched $\mathrm{Sr}$.

The concentration of $\mathrm{Zr}, \mathrm{Y}, \mathrm{Nb}$, and Co may reflect the nature of the fluids giving rise to hydrothermal deposition at Hole 424. Since $\mathrm{Nb}, \mathrm{Zr}$, and $\mathrm{Y}$ are pneumatophyle elements often concentrated in residual fluids of basaltic magmas (Gerasimovsky, 1974), any abnormal concentration of these elements implies a magmatic-hydrothermal affiliation. The relative low contents of these cations in Site 424 samples therefore indicate that fluids have mineralized these sediments were not directly derived from residual brines of a magmatic system. The hydrogeological setting, then, must be one of downward percolating sea water that becomes heated and rises along appropriate fracture patterns (Lonsdale, 1977).

Most of the sediments analyzed from Site 424 are hydrothermally derived. Only Sample 424-2-4, 130-132 cm is an unaltered, calcite-bearing, pelagic sediment. Samples 424-1-1, 2-4 cm; 424-2-4, 29-31 cm; 424-4-6, 83-85 $\mathrm{cm}$; and 424B-1-2, 67-69 $\mathrm{cm}$ consist of mixtures, apparently created by drilling disturbance and contamination during coring, of hydrothermal and pelagic sediments.

Analyses of the noncarbonate portion (oxide crusts and clays) of the sediment at Hole 424 suggest a hydrothermal affiliation. Three classes of sediment types were discovered by these analyses; they are reported here together with their average analysis results (15 analyses each):

Class 1 (Silica-rich, iron-rich green clays): $\mathrm{SiO}_{2}$ : $44 \%$; Mn: $0.06 \%$; Fe: $19 \%$; Co: 28 ppm; Cu: 10 ppm; Ni: 25 ppm; U: 0.5 ppm; Zn: 40 ppm.

Class 2 (Silica-poor, iron-rich clay-oxide mixtures): $\mathrm{SiO}_{2}: 1.1 \%$; Mn: $34.0 \%$; Fe: $7.2 \%$; Co: 21 ppm; Cu: 20 ppm; Ni: 70 ppm; U: 11 ppm; $\mathrm{Zn}: 95 \mathrm{ppm}$.

Class 3 (Silica-poor, iron-poor oxide crusts): $\mathrm{SiO}_{2}$ : $0.8 \%$; Mn: $46 \%$; Fe: $0.2 \%$; Co: 11 ppm; Cu: $42 \mathrm{ppm}$; Ni: 88 ppm; U: 14 ppm; Zn: 161 ppm.

The three classes of sediments are not distinct chemical entities, because Class 2 material (comprising black to dark brown nodules and crusts) appears to be intermediate between the other two classes which approximate chemical end members. Its microscopic study disclosed that these deposits consist of an intimate physical mixture of Class 1 material and opaque coatings and granules. The materials were separated by hand under a binocular microscope, and the components were ex- 
amined by X-ray diffraction. The results are tabulated as follows:

Class 1 grains: Mixed layered clay, major peak at $11.0 \AA$ on $\mathrm{Mg}$-saturation and $17.0 \AA$ on $\mathrm{Mg}$-saturation and glycolation.

Opaque granules and crusts coating Class 1 grains: Todorokite, birnessite, minor manganite, amorphous Fe-Mn (?) oxides.

The coated clay particles were found to be chemically identical to Class 1 sediments, and the oxides were defined as Class 3 sediments. Average whole-rock analyses of Class 3 and Class 1 sediments are as follows:

\begin{tabular}{|c|c|c|c|c|c|c|}
\hline & $\mathrm{SiO}_{2}$ & $\mathrm{Fe}_{2} \mathrm{O}_{3}$ & $\mathrm{Al}_{2} \mathrm{O}_{3}$ & $\mathrm{CaO}$ & $\overline{\mathrm{MgO}}$ & \\
\hline Class 3 (oxides): & $0.93 \%$ & $0.26 \%$ & $0.23 \%$ & $1.8 \%$ & $2.0 \%$ & \\
\hline \multirow[t]{2}{*}{ Class 1 (clays): } & $46 \%$ & $28 \%$ & $0.34 \%$ & $0.3 \%$ & $4.2 \%$ & \\
\hline & $\mathrm{TiO}_{2}$ & $\mathrm{MnO}$ & $\mathrm{Na}_{2} \mathrm{O}$ & $\mathrm{K}_{2} \mathrm{O}$ & $\mathrm{Ni}$ & \\
\hline Class 3: & $0.01 \%$ & $56.5 \%$ & $3.9 \%$ & $0.5 \%$ & $89 \mathrm{ppm}$ & \\
\hline \multirow[t]{2}{*}{ Class 1: } & $0.02 \%$ & $0.08 \%$ & $1.4 \%$ & $3.0 \%$ & $18 \mathrm{ppm}$ & \\
\hline & $\mathrm{Cu}$ & $\mathrm{Zn}$ & $\mathrm{Cr}$ & Co & $\mathrm{Sr}$ & $\mathrm{V}$ \\
\hline \multirow{3}{*}{$\begin{array}{l}\text { Class 3: } \\
\text { Class 1: }\end{array}$} & $42 \mathrm{ppm}$ & $160 \mathrm{ppm}$ & $15 \mathrm{ppm}$ & $11 \mathrm{ppm}$ & $392 \mathrm{ppm}$ & $18 \mathrm{pp}$ \\
\hline & $15 \mathrm{ppm}$ & $35 \mathrm{ppm}$ & $36 \mathrm{ppm}$ & $23 \mathrm{ppm}$ & $24 \mathrm{ppm}$ & $23 \mathrm{ppm}$ \\
\hline & $\mathrm{Ba}$ & $\mathrm{P}_{2} \mathrm{O}_{5}$ & $\mathrm{Zr}$ & & & \\
\hline $\begin{array}{l}\text { Class 3: } \\
\text { Class 1: }\end{array}$ & $\begin{array}{l}2090 \mathrm{pp} \\
59 \mathrm{ppm}\end{array}$ & $\mathrm{n}_{0 . \overline{08} \%}$ & $\begin{array}{c}28 \mathrm{ppm} \\
6 \mathrm{ppm}\end{array}$ & & & \\
\hline
\end{tabular}

The green clays comprising layers intercalated with pelagic sediments in Hole 424B were analyzed and proved to be identical to the Class 1 sediments.

These samples are obviously different from average pelagic sediment as described by Turekian and Wedepohl (1961) or the Pacific surface sediments described by Cronan (1969). The silica-rich material, Class 1 , comprising green smectite, is chemically very similar to the hydrothermal deposit near transform fault $\mathrm{A}$ in the FAMOUS area as described by Hoffert et al. (1978). The silica-poor material, Class 3 , is low in $\mathrm{Co}, \mathrm{Cu}, \mathrm{Ni}$, and $\mathrm{Fe}$ relative to reported concentrations of these elements in typical Fe-Mn nodules of the East Pacific (Cronan, 1973; and Cronan and Tooms, 1969). The U contents of the silica-poor sediments are similar, however, to both Pacific and Atlantic nodules of diagenetic origin (Schrader, unpublished research). The data are somewhat conflicting, but the authors feel that the association of this material with the "Mounds Area" (Lonsdale, 1977; Site Report, this volume), the intimate intercalation of the two noncarbonate materials, and the low transition-element contents of these sediments imply a hydrothermal origin for both classes of noncarbonate material. If this deduction is correct, then Leg 54 has retrieved and identified a new mode of sea-floor hydrothermal sedimentation which is silica-poor, Fe-poor, and Mn-rich.

\section{ELEMENTAL AND OXIDE RELATIONSHIPS}

Additional variations in trace metal concentrations can be observed in depth versus concentration diagrams. Figures 2, 3, 4, and 5 display $\mathrm{CaO}, \mathrm{Sr}$, and $\mathrm{P}_{2} \mathrm{O}_{5}$ variations with depth below the sediment/water interface. In general, the $\mathrm{CaO}$ and $\mathrm{Sr}$ curves are similar ow-
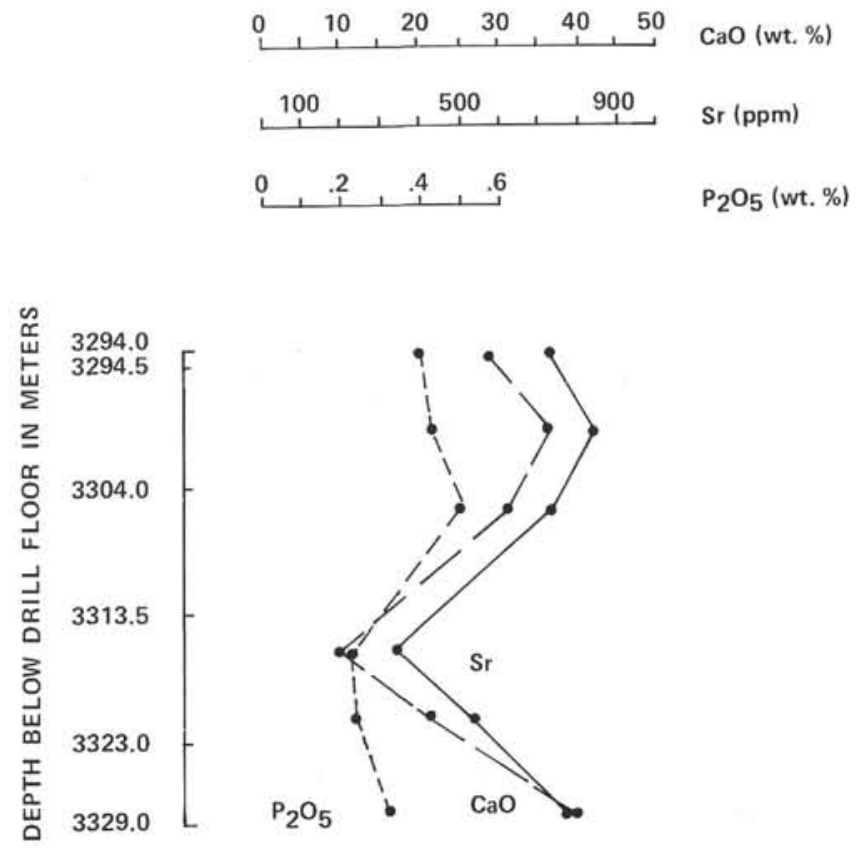

Figure 2. Depth versus $\mathrm{CaO}, \mathrm{Sr}$, and $\mathrm{P}_{2} \mathrm{O}_{5}$ concentrations in sediment from Site 419.

ing to the $\mathrm{Sr}$ affinity for the calcite lattice. Only in the deepest sample in Hole 424 does Sr strongly deviate from $\mathrm{CaO}$. Since this site is strongly influenced by hydrothermal fluids, we must assume that this deviation is the result of a geochemical separation of these cations by hydrothermal processes.

$\mathrm{P}_{2} \mathrm{O}_{5}$ can be seen to fluctuate more or less independently of $\mathrm{CaO}$ (Figures 2, 3, 4, and 5). The $\mathrm{P}_{2} \mathrm{O}_{5}$ contents of surface or near-surface sediments is consistently higher than the lowest sample in each core. The lower $\mathrm{P}_{2} \mathrm{O}_{5}$ values in the surface sediments reflect either a heavier deposition of possible skeletal debris in recent times or a diagenetic solution and removal of the phosphate-bearing compounds near the basalt/sediment interface. The only exception to this relationship is seen again at Site 424 , where the deepest sample is strongly enriched in $\mathrm{P}_{2} \mathrm{O}_{5}$. The effect of hydrothermal solutions is a possible cause. Downward percolating seawater may have dissolved phosphatic material in sediments and P-bearing phases in basalts. These solutions, when encountering porous and reactive sediment above basalt (during their ascent), may have deposited a portion of their chemical burden in the form of $\mathrm{P}_{2} \mathrm{O}_{5}$ and $\mathrm{Sr}$. It is also possible that these elevated concentrations of $\mathrm{Sr}$ and $\mathrm{P}_{2} \mathrm{O}_{5}$ represent heightened dissolution of $\mathrm{CaCO}_{3}$, perhaps by hydrothermal fluids, and are thus residually concentrated ichthyolite debris.

The relationship between $\mathrm{Fe} / \mathrm{Mn}$ and $\mathrm{Co}$ is displayed in Figure 6. Schrader et al. (1976) discussed the relationship of base metals to $\mathrm{Fe}$ and $\mathrm{Mn}$ oxides. They found that in the case studied, base metals were preferentially concentrated in the Mn oxides. The same relationship is observable in the samples of the present study, although it is complicated by the presence of two apparent trends. As can be seen in Figure 6, the entire field of data can be 


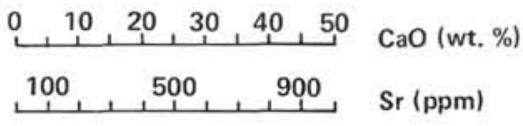

$\stackrel{0}{0,2}, .4, .6$

$\mathrm{P}_{2} \mathrm{O}_{5}$ (wt. \%)

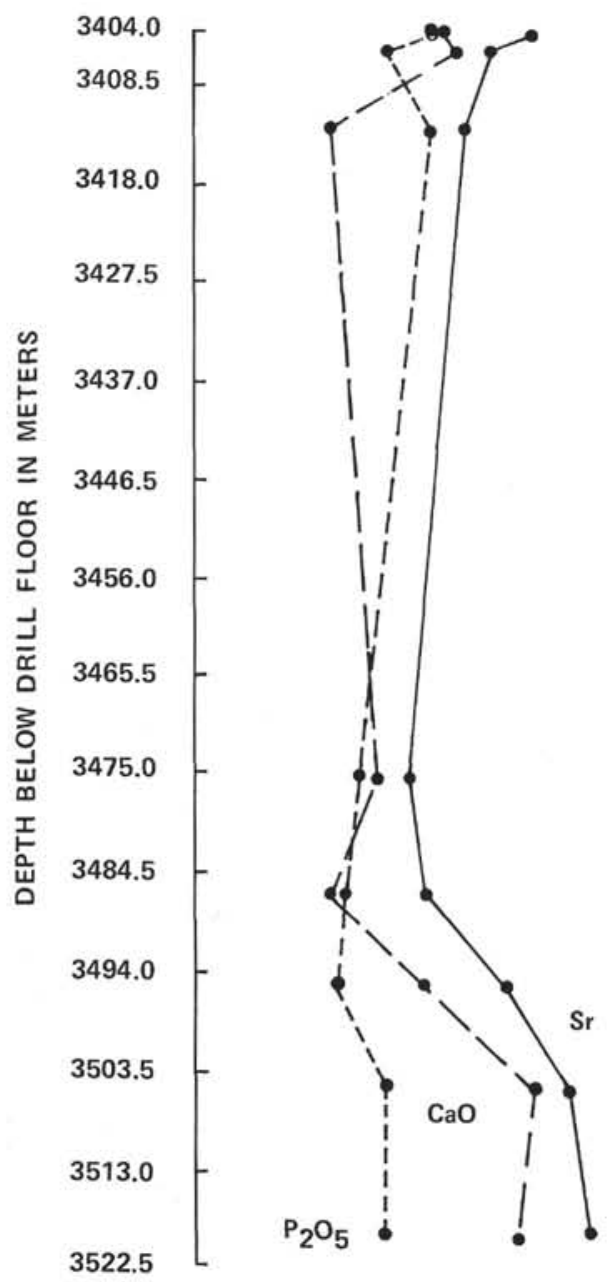

Figure 3. Depth versus $\mathrm{CaO}, \mathrm{Sr}$, and $\mathrm{P}_{2} \mathrm{O}_{5}$ concentrations in sediment from Site 420.

described by a hyperbolic curve. If, however, only the data points with Co concentrations below $150 \mathrm{ppm}$ and $\mathrm{Fe} / \mathrm{Mn}$ ratios below 35 were considered, then the curve describing these points would become less well defined and the relationship obscure. Apparently, high Fe concentrations correlate with lower Co values, and the higher Mn values correspond to increased Co levels. However, in the range of $\mathrm{Fe} / \mathrm{Mn}$ ratios of 2 to 40 no trend is actually discernible.

The typical linear relationship of $\mathrm{K}$ to $\mathrm{Rb}$ is observable in Figure 7. The coherent relationship between the elements as described by Ahrens et al., (1952) is evident. The upper half of the trend is completely dominated by the samples from Hole 424. We attribute this to a hydrothermal component contributing both elements for fixation in smectites as substitutional ions within lattices and as sorbed ions on oxide and smectite surfaces.
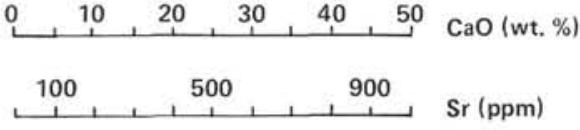

$0, .2, .4, .6 \quad \mathrm{P}_{2} \mathrm{O}_{5}$ (wt. \%)

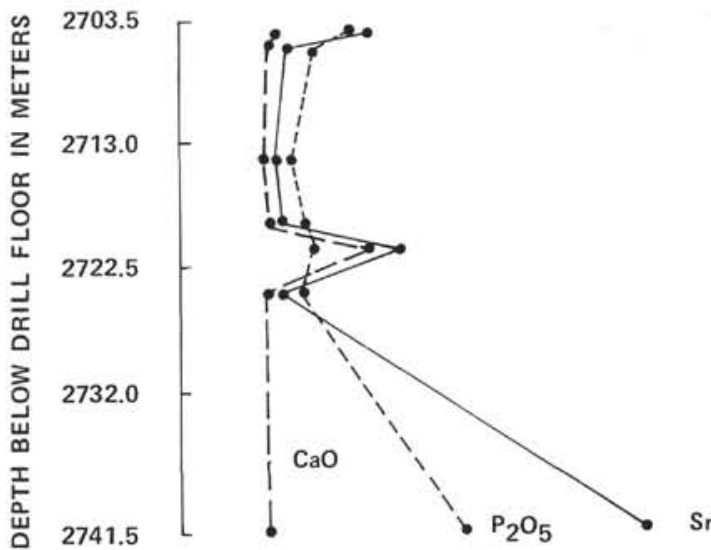

Figure 4. Depth versus $\mathrm{CaO}, \mathrm{Sr}$, and $\mathrm{P}_{2} \mathrm{O}_{5}$ concentrations in sediment from Site 424.
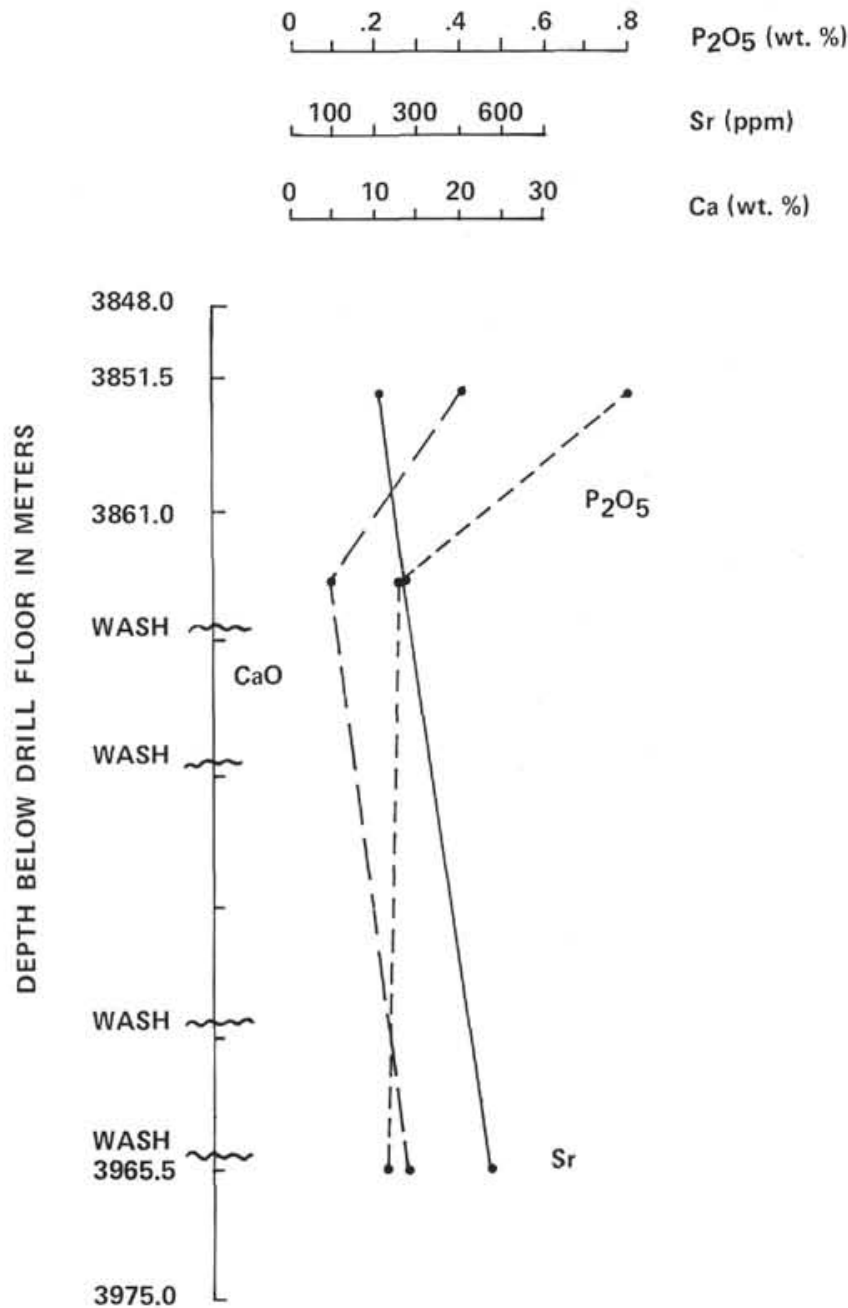

Figure 5. Depth versus $\mathrm{CaO}, \mathrm{Sr}$, and $\mathrm{P}_{2} \mathrm{O}_{5}$ concentrations in sediment from Site 427. 


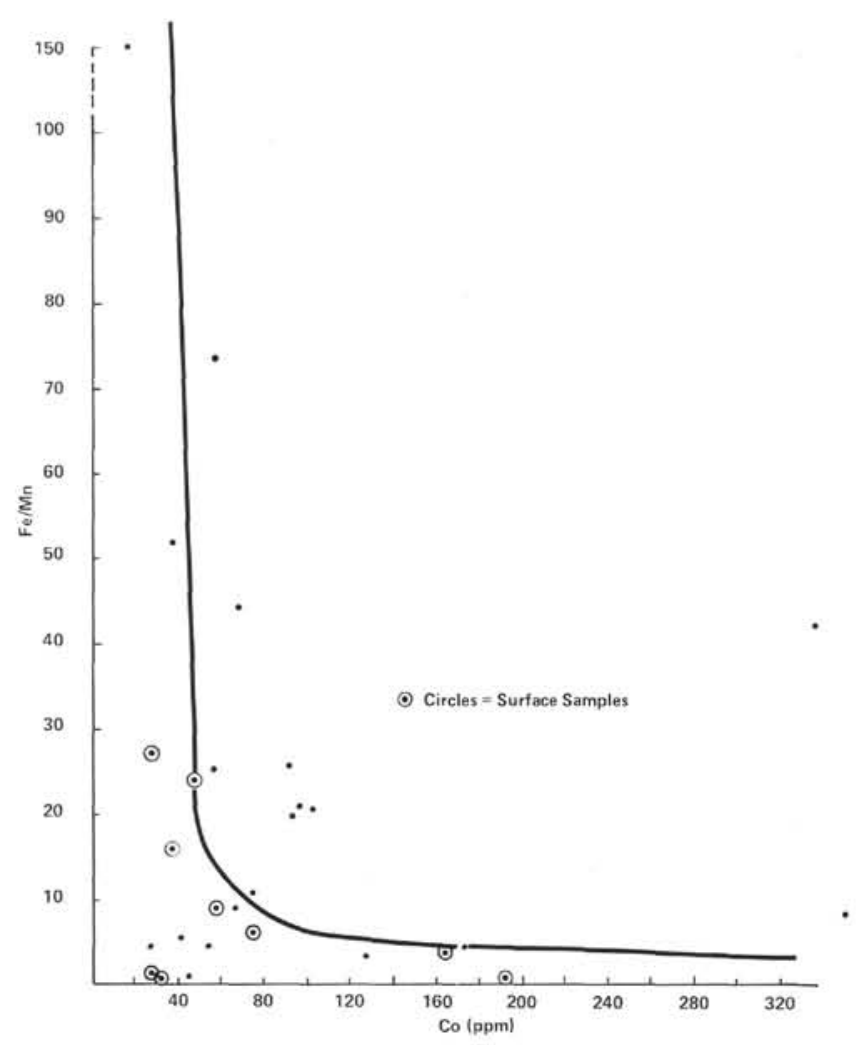

Figure 6. $\mathrm{Fe} / \mathrm{Mn}$ versus Co(ppm) for all analyzed sediment samples. The curve is a best-fit, regular geometrical approximation of the data.

Future work is planned to determine the nature of the enrichment of these cations.

In a similar graph, Figure 8 displays the fairly incoherent scatter of points relating $\mathrm{Sr}$ to $\mathrm{Rb}$. It is interesting to note, however, that the three surface sediments that plot in a nearly linear fashion in the lower third of the graph are all from the "Mounds Hydrothermal Field." Again, the low $\mathrm{CaO}$ content of the hydrothermal sediments predicts that $\mathrm{Sr}$ will also be depleted. In fact, the four points with $\mathrm{Sr}$ contents less than 100 ppm are all samples from Hole 424. Perhaps, then, the shaded portion of the graph may approximate a field occupied by deposits of hydrothermal affiliation at least in the Galapagos region. It is also interesting to note that the only other point falling in this field is Sample $427-2-1,30-32 \mathrm{~cm}$. We have previously postulated the hydrothermal affiliation of this sediment as due to its $\mathrm{Fe} /$ $\mathrm{Mn}$ reversal. Alteration of silicate phases and hydrothermal sulfide veining are reported in the basement basalts of Site 427 by Schrader and Furbish (Mineralogy and geochemistry of ore minerals, etc., this volume).

\section{BULK X-RAY DIFFRACTION MINERAL IDENTIFICATION}

The most intense peak for each mineral phase identified in the sediment cores is presented in Table 3.

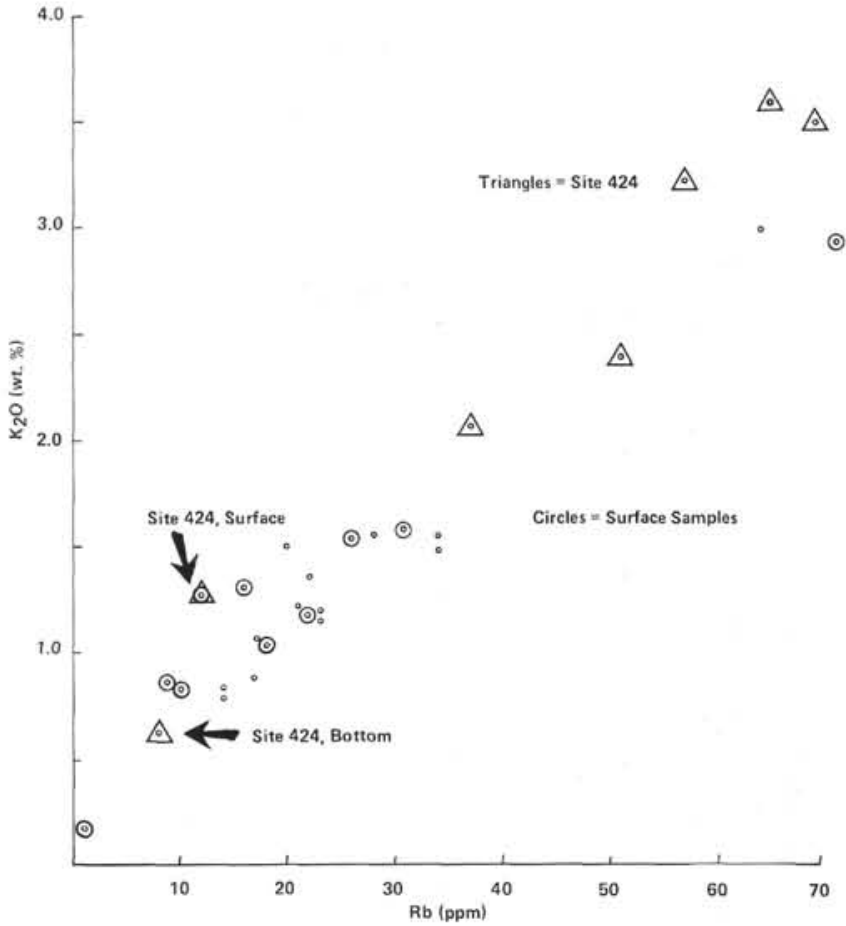

Figure 7. $\mathrm{K}_{2} \mathrm{O}(w t . \%)$ versus $\mathrm{Rb}(\mathrm{ppm})$ for all analyzed sediment samples.

Calcite is by far the dominant constituent, decreasing in relative abundance in Hole 424 in the Mounds Hydrothermal Field. Saponite is nearly ubiquitous throughout the samples, showing no relative increase in intensity or crystallinity at Hole 424 . Chlorite is generally absent, although it does appear in the upper two samples from Hole 424 and the surface sample from Hole 424A.

Two minerals occur in Hole 427 samples that are not seen in other cores: dolomite and pyrite. Dolomite occurs in the surface sample from Hole 427 and corresponds to a decrease in $\mathrm{Rb}, \mathrm{Sr}$, and $\mathrm{K}_{2} \mathrm{O}$ relative to underlying sediment. These relative depletions and the low intensity of the calcite peaks indicate that the ordered dolomite lattice is less capable of holding these cations in substitutional sites and that the volume of calcite present is insufficient to accommodate the trace quantities found in other samples. The high $\mathrm{P}_{2} \mathrm{O}_{5}$ content $(0.79 \mathrm{wt} . \%)$ is reflected in the occurrence of collophane as a grain coating and minor matrix constituent of the lithic nodules found in this portion of the core.

The presence of pyrite in Sample 427-3-3, 81-83 cm is megascopically noticeable in the core as disseminated black flecks in an apparently unaltered carbonate ooze. The pyrite is thought to be diagenetic and the result of $\mathrm{H}_{2} \mathrm{~S}$ fixation and reduction of $\mathrm{Fe}^{+3}$ ions in the pore waters; it is accompanied by an increase in $\mathrm{Co}, \mathrm{Cu}, \mathrm{Fe}$, $\mathrm{Zn}$, and Mo relative to the surrounding sediments. These elements apparently are incorporated in the poorly crystalline pyrite, since no sulfides or other minerals containing these cations as major constituents are present in the sample. 
๑

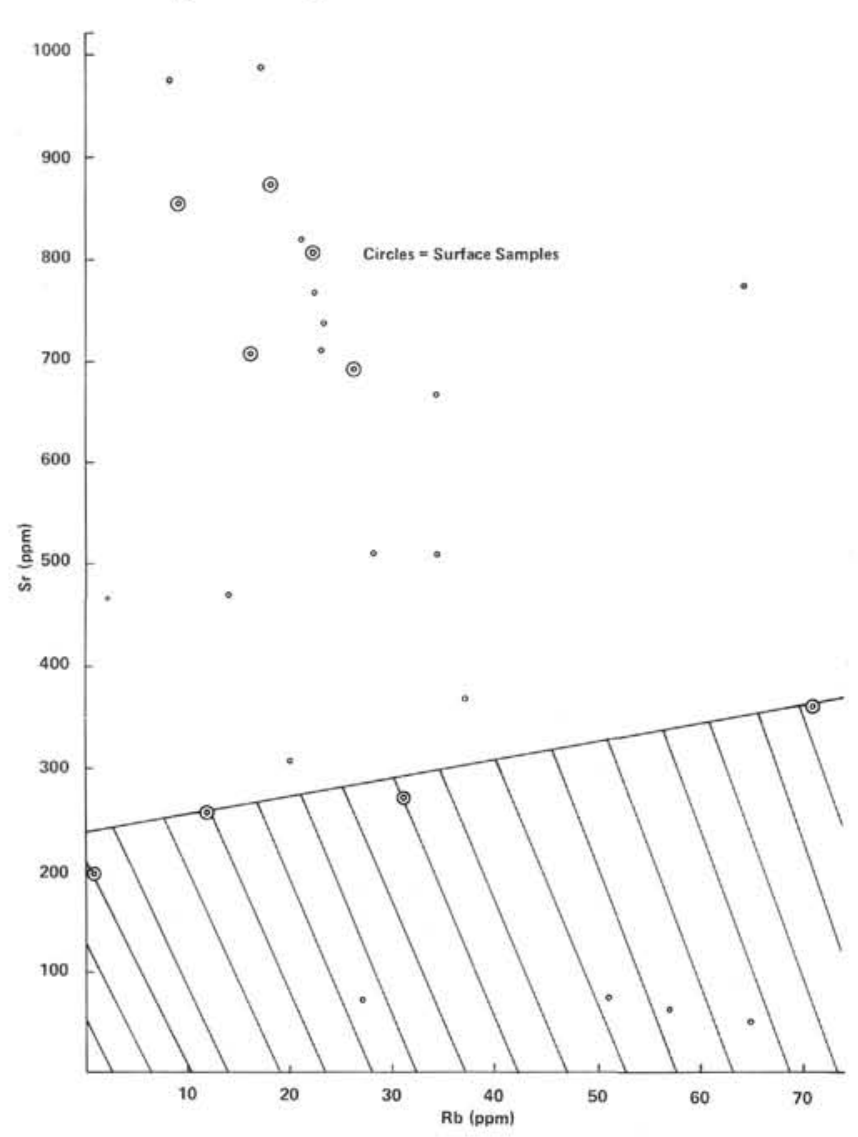

Figure 8. $\operatorname{Sr}(\mathrm{ppm})$ versus $R b(\mathrm{ppm})$ for all analyzed sediment samples. Shaded area represents field dominated by hydrothermally affiliated samples.

\section{CARBONATE PETROLOGY OF LITHIC NODULES}

\section{Sample Descriptions}

Eleven thin sections of carbonate oozes directly overlying basalts of the EPR region were examined (Table 2). The majority are foraminiferal biomicrite (Folk, 1962) or foraminifer wackestone (Dunham, 1962). The foraminifers are predominantly Globoratalia spp. and Globogerina spp.; other fossils include biserial foraminifers, diatoms, radiolarians, and unidentified minute fragments. The matrix is light tan to dark brown, highmagnesium calcite, with a crystal size usually less than 5 $\mu \mathrm{m}$. Bioclasts are rarely in contact, at most in point contact, separated by the micrite. Some foraminifer tests are completely filled in with sediment, although incomplete sediment infilling of the chambers is the rule. Partially filled tests display a systematic flooring, the result of carbonate mud filtering in under the influence of gravity, allowing for the orientation of the samples. Numerous other samples contain unfilled tests, which display an incipient internal rim of blunt and short $(<10 \mu \mathrm{m})$ magnesium calcite druse. These secondary crystals parallel the sweeping extinction of the shell wall when rotated under polarized transmitted light with crossed nicols, and appear to be overgrowths in optical
TABLE 3

X-Ray Diffraction Mineral Identification of Unwashed Sediment

\begin{tabular}{|c|c|c|c|c|c|c|c|}
\hline \multirow{3}{*}{$\begin{array}{c}\text { Sample } \\
\text { (Interval in cm) }\end{array}$} & \multicolumn{7}{|c|}{ Relative Value of the Most Intense X-Ray Peaks } \\
\hline & \multirow[b]{2}{*}{ Calcite } & \multirow[b]{2}{*}{ Quartz } & \multirow[b]{2}{*}{ Halite } & \multicolumn{2}{|c|}{ Smectite } & \multirow[b]{2}{*}{ Dolomite } & \multirow[b]{2}{*}{ Pyrite } \\
\hline & & & & Saponite & Chlorite & & \\
\hline \multicolumn{8}{|l|}{ Hole 419} \\
\hline $1, \mathrm{CC}, 2-4$ & 60 & 8 & 3 & 7 & - & - & - \\
\hline $2-3,53-55$ & 70 & $?$ & 3 & 6 & - & - & - \\
\hline $3-1,91-93$ & 87 & 12 & 8 & 9 & 11 & - & - \\
\hline $4-2,92-94$ & 30 & 9 & 17 & 10 & 0.5 & - & - \\
\hline $4-5,13-15$ & 41 & $?$ & $\approx$ & 8 & & - & - \\
\hline $5, \mathrm{CC}, 1-2$ & 95 & 5 & 4 & 6 & - & - & - \\
\hline \multicolumn{8}{|l|}{ Hole 419A } \\
\hline $1-3,132-134$ & 82 & 12 & 5 & 10 & - & - & - \\
\hline \multicolumn{8}{|l|}{ Hole 420} \\
\hline $1-1,10-12$ & 82 & 10 & 6 & 7 & - & - & - \\
\hline $2-3,70-72$ & 28 & 12 & 5 & 7 & - & - & - \\
\hline $9-1,10-12$ & 55 & 8 & 6 & 7 & & - & - \\
\hline $10-2,41-43$ & 31 & 9 & 5 & 10 & & & - \\
\hline $11-2,15-17$ & 100 & 6 & - & 7 & - & - & - \\
\hline $\begin{array}{l}12-2,50-52 \\
3-4,130-132\end{array}$ & 100 & $\overline{5}$ & $\begin{array}{l}5 \\
4\end{array}$ & $\begin{array}{l}5 \\
5\end{array}$ & - & - & - \\
\hline \multirow{2}{*}{\multicolumn{8}{|c|}{ Hole $420 \mathrm{~A}$}} \\
\hline & & & & & & & \\
\hline $1-1,24-26$ & 68 & 11 & - & 8 & - & - & \\
\hline \multicolumn{8}{|l|}{ Hole 424} \\
\hline $1-1,97-99$ & - & - & 5 & 9 & 9 & - & - \\
\hline $1-2,67-69$ & 40 & - & 6 & 12 & 10 & & - \\
\hline $2-1.50-52$ & - & - & - & 6 & & - & \\
\hline $2-4.29-31$ & 6 & - & - & 10 & - & - & - \\
\hline $2-4,130-132$ & 35 & 6 & 4 & 9 & - & - & - \\
\hline $\begin{array}{l}3-1,27-29 \\
4-6,83-85\end{array}$ & 40 & 5 & 7 & $\begin{array}{l}6 \\
4\end{array}$ & - & - & $\bar{z}$ \\
\hline \multicolumn{8}{|l|}{ Hole 424A } \\
\hline $1-1,77-79$ & 20 & 7 & 29 & 8 & 10 & - & - \\
\hline \multicolumn{8}{|l|}{ Hole 425} \\
\hline $1-1,13-15$ & 115 & - & 11 & 8 & - & & - \\
\hline \multicolumn{8}{|l|}{ Hole 427} \\
\hline $2 \cdot 1,30-32$ & 13 & 3 & - & - & - & 46 & - \\
\hline $3-3,81-83$ & 41 & $=$ & 8 & 9 & 5 & - & 12 \\
\hline $8-1,18-20$ & 43 & - & 11 & 12 & 7 & & - \\
\hline \multicolumn{8}{|l|}{ Hole 429} \\
\hline $1-1,90-92$ & 115 & 5 & 4 & 6 & - & - & - \\
\hline
\end{tabular}

continuity with the tests. Two foraminifer chambers display a small grouping of radiating acicular crystals up to $20 \mu \mathrm{m}$ long. Although resembling "whisker calcite," these also may represent crystallization by noncarbonate minerals.

In contrast, broken fragments make up a majority of the bioclasts in some samples, and are "floating" within the matrix. Still other samples almost completely lack bioclastic material, and have a clotted or pelleted appearance. These might be termed pelletoidal packstones (Dunham, 1962). Regardless of bioclastic make-up, most samples display mottling of the micrite, owing to bioturbation. Many still retain open burrows, some of which have organically stained walls, although one burrow with a darkened border was filled in with creamcolored carbonate mud. Numerous samples have patches and spherules which are opaque in transmitted light, but orange to reddish brown in reflected light. These are believed to be ferromanganese oxides.Patches of an unidentified yellow material (translucent under transmitted light) occur in lesser amounts. Many thin sections display rare anhedral quartz grains and elongate shards, which may be original or replaced microfossil fragments. 
Only one sample contains calcite filling a fracture. Nowhere can the underlying volcanic material be seen to be worked up into the carbonates.

\section{Discussion}

If preserved in the rock record, these samples would portray an heterogeneous suite of fine-grained carbonates. Variations are observed in porosity, mottling, dissolution/recrystallization, presence of noncarbonate minerals, pelleted versus nonpelleted matrix, both the amount and types of bioclasts, and whole versus broken tests. The accompanying volcanic rocks do not exert a uniform influence on recrystallization; even when in direct contact with the basalts, no change in the overlying carbonate fabric is visible. However, the presence of noncarbonate phases and stains indicates that geochemical and/or biochemical reactions have taken place.

An interesting aspect is the great variation in paragenetic sequences displayed by these samples. There is no grading of fossils or apparent working of the sediments, yet some samples consist wholly of broken tests while others are an admixture of whole and broken bioclasts. This leads to variations in porosity because the whole tests are rarely completely filled. Even those chambers which are ruptured upon compaction remain relatively unfilled. Fragmentation may have arisen through diverse means, such as chemical dissolution and disarticulation before or after sedimentation, or by physical processes, such as reworking of the sediments by benthic organisms. Most tests appear to retain the original shell wall architecture, although some display patches of recrystallization which go to extinction under crossed nicols. Internal cementation by an incipient primary pore-filling druse is present only within those chambers that do not display micrite infilling. This sediment flooring appears to have been an early process, preventing any internal cementation in those tests where present. No tests display complete filling by pore-filling cement.

A great variability in diagenetic pathways may be inferred from this thin section analysis. Even within those samples directly in contact with volcanic rocks, there has been no extensive or uniform recrystallization. However, the presence of noncarbonate materials indicates some diagenetic influence owing to biochemical and/or geochemical reactions. Of special interest is the heterogeneity displayed by these samples, although deposited within and diagenetically controlled by relatively equivalent environments.

\section{SUMMARY AND CONCLUSIONS}

To summarize chemical relationships between the sediments reported here and to compare the present study with previous work, Table 4 is provided. Obviously, major variations exist both within the sediments of the present study and between these sediments and the previously reported metal concentrations of Pacific sediments.

Sites 419,420 , and 427 are generally higher in $\mathrm{Fe}, \mathrm{Zn}$, and $\mathrm{Sr}$ than previously reported Pacific clays (Table 4; B and $C$ ) and the average of pelagic clays (Table $4 ; A$ ).
TABLE 4

Average of Selected Trace Metal Compositions in Pacific Sediments (ppm)

\begin{tabular}{|c|c|c|c|c|c|}
\hline Leg 54, Sites/Previous Studies & $\mathrm{Fe}(\%)$ & Co & $\mathrm{Cu}$ & $\mathrm{Zn}$ & $\mathrm{Sr}$ \\
\hline 419 & 8.31 & $115(71)$ & 150 & 290 & 638 \\
\hline 420 & 6.48 & 96 & 178 & 242 & 755 \\
\hline 424 & 16.17 & 38 & 147 & $117(69)$ & $259(140)$ \\
\hline 427 & $9.21(5.06)$ & 238 & 203 & 260 & 306 \\
\hline A) Pelagic claya & 6.50 & 74 & 250 & 165 & 180 \\
\hline B) 19 Brown Pacific clays ${ }^{b}$ & 5.39 & 55 & 239 & 154 & 228 \\
\hline C) Surface Pacific pelagic clays ${ }^{C}$ & 5.06 & 101 & 323 & - & - \\
\hline D) 7 EPR sediments ${ }^{\mathrm{d}}$ & 18.00 & 105 & 730 & 380 & - \\
\hline $\begin{array}{l}\text { E) } 11 \text { Ferruginous sediments from } \\
\text { Sites } 159,160 \text {, and } 162^{\mathrm{e}}\end{array}$ & 17.50 & 83 & 917 & 358 & - \\
\hline Crustal abundances & 5.63 & 25 & 55 & 70 & 375 \\
\hline $\begin{array}{l}\mathrm{a}=\text { Turekian and Wedepohl, } 1961 . \\
\mathrm{b}=\text { Burnett, } 1971 . \\
\mathrm{c}=\text { Cronan, } 1969 . \\
\mathrm{d}=\text { Bostrom and Peterson, } 1969 . \\
\mathrm{e}=\text { Cronan and Garret, } 1973 . \\
\mathrm{f}=\text { Taylot, } 1964 .\end{array}$ & & & & & ( \\
\hline
\end{tabular}

The Co contents of the sediments from these sites are similar to averages A, B, and C, while their $\mathrm{Cu}$ concentrations are lower than these averaged values. The increased $\mathrm{Fe}$ and transition elements at Site 427 may be due to hydrothermal components of the sediment.

The sediments of Site 424 are similar to ferruginous deposits ( $\mathrm{D}$ and $\mathrm{E}$ in Table 4) of the EPR in their Fe content. The low transition-element concentrations of the Mounds area deposits correlate with other documented occurrences of hydrothermal deposits (Hoffert, 1978). Although Fe-rich sediments of the East Pacific have been postulated as hydrothermal in origin (D and E, Table 4), it is evident that they were not deposited from fluids similar in composition to those responsible for topographic build-up in the Mounds Hydrothermal Field.

On the whole, the authors feel that any or all of the sediments studied may have a component directly related to hydrothermal deposition. The common recrystallization and dissolution of carbonate tests in the lithic nodules studied may be a chemical response to these circulating fluids. Perhaps the fact that the Fe contents of most of the sediments studied are higher than those of older sediments reflects diagenetic adjustment of the metal with time. The fingerprint of slight or subtle hydrothermal effects may thus be lost with minor redistribution of the previously deposited elements.

\section{ACKNOWLEDGMENT}

The authors gratefully acknowledge critical review of this manuscript and stimulating discussions offered by Dr. N. E. Cygan and Mr. M. J. Holtzclaw, Chevron Resources Company, Denver, Colorado.

\section{REFERENCES}

Ahrens, L. H., Pinson, W. H., and Kearns, M. M., 1952. Association of rubidium and potassium and their abundance in common igneous rocks and meteorites. Geochim. Cosmochim. Acta, v. 2, p. 229-242.

Boström, K., Joensuu, O. J., Valdes, S., Charm, W., and Glaccum, R., 1976. Geochemistry and origin of East Pacific sediments sampled during DSDP Leg 34. In Yeats, R. S., Hart, S. R., et al., Initial Reports of the Deep Sea Drilling Project, v. 34: Washington (U. S. Government Printing Office) p. 559-574. 
Boström, K., Kraemer, T., and Gartner, S., 1973. Provenance and accumulation rates of opaline silica, $\mathrm{Al}, \mathrm{Ti}, \mathrm{Fe}, \mathrm{Mn}$, $\mathrm{Cu}, \mathrm{Ni}$, and $\mathrm{Co}$ in Pacific pelagic sediments. Chem. Geol., v. 11, p. $123-148$.

Boström, K., and Peterson, M. N. A., 1969. The origin of aluminum-poor ferromanganoan sediments in areas of high heat flow on the East Pacific Rise. Mar. Geol., v. 7, p. 427-447.

Burnett, W. C., 1971. Trace element variations in some central Pacific and Hawaiian sediments [Unpublished Master's Thesis]. Hawaii Institute of Geophysics, University of Hawaii.

Cronan, D. S., 1969. Average abundances of Mn, Fe, Ni, Co, $\mathrm{Cu}, \mathrm{Pb}, \mathrm{Mo}, \mathrm{V}, \mathrm{Ce}, \mathrm{Ti}$, and $\mathrm{P}$ in Pacific pelagic clays. Geochim. Cosmochim. Acta, v. 33, p. 1562-1565.

1973. Basal ferruginous sediments cored during Leg 16, Deep Sea Drilling Project. In van Andel, Tj. H., Heath, G. R., et al., Initial Reports of the Deep Sea Drilling Project, v. 16: Washington (U. S. Government Printing Office), p. 601-604.

1976. Basal metalliferous sediments from the Eastern Pacific. Geol. Soc. Am. Bull., v. 87, p. 928-934.

Cronan, D. S., and Garret, D. E., 1973. Distribution of elements in metalliferous Pacific sediments collected during the Deep Sea Drilling Project. Nature, v. 242, p. 88-89.

Cronan, D. S., and Tooms, J. S., 1969. The geochemistry of manganese nodules and associated pelagic deposits from the Pacific and Indian Oceans. Deep-Sea Res., v. 16, p. 335-359.

Dunham, R. J., 1962. Classification of carbonate rocks according to depositional texture. In Ham, W. D. (Ed.), Classification of Carbonate Rocks: A. A. P. G., Memoir no. 1, p. 108-121.

Dymond, J., Corliss, J. B., and Sitillinger, R., 1976. Chemical compositions and metal accumulation rates of metalliferous sediments from Sites 319, 320, and 321. In Yeats, R. S., Hart, S. R., et al., Initial Reports of the Deep Sea Drill- ing Project, v. 34: Washington (U. S. Government Printing Office), p. 575-588.

Folk, R. L., 1962. Spectral subdivision of limestone types. In Ham, W. D. (Ed.), Classification of Carbonate Rocks: A.A.P.G., Memoir No. 1, p. 62-84.

Gerasimousky, V. I., 1974. Trace elements in selected groups of alkaline rocks. In Sorensen, H. (Ed.), The Alkaline Rocks: New York (John Wiley and Sons), p. 402-411.

Hoffert, M., Perseil, A., Hekinian, R., Choukroune, P., Needham, H. D., Francheteau, J., and LePichon, X., 1978. Hydrothermal deposits sampled by diving saucer in transform fault A near $37^{\circ} \mathrm{N}$ on the Mid-Atlantic Ridge FAMOUS area. Oceanologica Acta, v. 1, p. 73-86.

Krauskopf, K. B., 1957. Separation of manganese from iron in sedimentary processes. Geochem. Cosmochim. Acta, v. 12, p. 61-84.

1967. Geochemistry: New York (McGraw-Hill)

Lonsdale, P., 1977. Deep-tow observations at the mounds abyssal hydrothermal field, Galapagos Rift. Earth Planet. Sci. Lett., v. 36, p. 92-110.

Natland, J. H., 1973. Basal ferromanganoan sediments at DSDP Site 183, Aleutian abyssal plain, and Site 192, Meiji guyot, Northwest Pacific, Leg 19. In Creagar, J. S., School, D. W., et al., Initial Reports of the Deep Sea Drilling Project, v. 19: Washington (U. S. Government Printing Office), p. 629-640.

Schrader, E. L., Rule, J. H., and Furbish, W. J., 1976. Trace element geochemistry of a fluvial system in eastern Tennessee affected by coal mining. Southeastern Geol., v. 18, p. $157-172$.

Stanton, R. L., 1972. Ore Petrology: New York (McGrawHill).

Taylor, S. R., 1964. Abundance of chemical elements in the continental crust: a new table. Geochim. Cosmochim. Acta, v. 28, p. 1479-1496.

Turekian, K. K. and Wedepohl, K. H., 1961. Distribution of the elements in some major units of the Earth's crust. Bull. Geol. Soc. Am., v. 72, p. 175-192. 